\title{
Sosiaalisen talouden ja solidaarisuustalouden skaalautumisesta
}

\section{Tuomo Alhojärvi}

Utting, Peter (toim.; 2015) Social and Solidarity Economy Beyond the Fringe. Lontoo: Zed Books.

Vaihtoehtoja uusliberaalille taloudenpidolle ja kapitalistiselle harvainvallalle riittää. Suomessa aloitteita on koottu "talouden uusien muotojen" (Jakonen \& Silvasti 2015) sateenvarjokäsitteen alle, maailmalla käytyjä keskusteluja peilaten. Polkuja kapitalismin jälkeiseen yhteiskuntaan etsitään erilaisilla aloitteilla kohtuutaloudesta commonseihin, yhteiskunnallisesta yrittäjyydestä osallisuustalouteen. Peter Uttingin toimittama Social and Solidarity Economy Beyond the Fringe tuo tähän keskusteluun monipuolisia sosiaalisen ja solidaarisuustalouden esimerkkejä ympäri maailmaa. Teos perustuu YK:n sosiaalisen kehityksen tutkimuslaitoksen UNRISD:in (United Nations Research Institute for Social Development) hankkeeseen, jossa käsiteltiin sosiaalisen talouden ja solidaarisuustalouden potentiaaleja erityisesti kehitysproblematiikan kontekstissa. Ruohonjuuritasolta tarkastellen institutionaalisten toimijoiden kiinnostuminen sosiaalisesta ja solidaarisuustaloudesta on tervetullut aloite. Toisaalta se nostaa esille myös mielenkiintoisia jännitteitä ja tuo omat painolastinsa keskusteluihin.

Sosiaalisella taloudella ja solidaarisuustaloudella tarkoitetaan tässä yhteydessä pyrkimystä toisenlaisten arvojen ja demokraattisten prosessien tuomiseksi talouden kentille. Käsiteparin sisällä on mielenkiintoinen ja kirjassa tiedostettu jännite. Sosiaalinen talous (social economy) on kompromissihakuisempi tulokulma. Se merkitsee pyrkimystä kasvattaa eettisiin arvoihin perustuvien ja "ihmiskeskeisten" organisaatioiden merkitystä taloudessa. Osuuskunnat, keskinäiset yhtiöt ja erilaiset voittoa tavoittelemattomat kolmannen sektorin toimijat rakentavat eettistä ja demokraattista neuvottelua talouden sisään ja ottavat arvoketjuja haltuun. Sosiaalisesta taloudesta puhuttaessa painottuvat usein taloustoimijoiden suhteet instituutioihin, 
uusien palveluntuotantomallien julkisia palveluja täydentävä luonne, sekä sosiaalisen talouden toimijoiden edellytykset pärjätä kilpailullisilla markkinoilla.

Solidaarisuustalous (solidarity economy) on käsiteparin poliittisesti kantaaottavampi puolisko. Käsitteen avulla asemoidaan talouden vaihtoehtoja suhteessa kapitalismiin. Solidaarisuustalouden järjestelmien tavoitteena on tuottaa kapitalistisista suhteista mahdollisimman vapaita verkostoja. Tavoitteena on mahdollisimman suora demokratia. Kyseessä on siis pikemmin poliittinen liike kuin luettelo ihanteellisista organisaatiomuodoista. Kritiikki institutionaalisempia ja väljähtyneiksi tulkittuja näkökulmia kohtaan on usein kovaa. Solidaarisuustalous on lähellä talouden haltuunoton anti- ja post-kapitalistisia liikkeitä, jotka esittävät esimerkiksi yhteisen (commons) vahvistamista, hyvinvoinnin irrottamista voitontavoittelusta ja talouskasvusta (degrowth) sekä perustuloa palkkatyöstä irrotettuna vastikkeettomana toimeentulona.

Uttingin toimittaman kirjan lähtökohtana on, että sosiaalista ja solidaarista on ajateltava yhdessä juuri näiden ristiriitojen takia. Kompromissihakuisen ja radikaalin näkökulman on haastettava toisiaan. Erilaisten tutkimuksellisten ja poliittisten strategioiden kohtaamisia tarvitaan myös. On haettava synergioita, kuten Jean-Louis Laville muotoilee tehtävän artikkelissaan, mutta myös otettava tosissaan elävien taloudellisten liikkeiden institutionalisoitumisesta seuraavat haasteet. Sosiaalisen talouden ja solidaarisuustalouden agenda on jännitteistä huolimatta sikäli johdonmukainen, että talouden vaihtoehtoja lähestytään jo olemassa olevien eettisesti virittyneiden talouden toimintojen kautta. Näihin uusiin talouden muotoihin sisältyy ajatus, että kaikessa ristiriitaisuudessaan ja epätäydellisyydessään monissa nykyisissä toiminnoissa on konkreettisia siemeniä kapitalismin ylittämiseksi.

Tämän kirjan osalta konkreettisuutta lähestytään kysymyksellä siitä, millä tavalla sosiaalisen talouden ja solidaarisuustalouden toiminnot voisivat skaalautua tai laajentua arvonsa ja poliittiset pyrkimyksensä säilyttäen. Kysymys ei ole vain kasvusta, vaan skaalautumisella tarkoitetaan tässä yhteydessä ruohonjuuritason toimijoiden lisääntymistä (horisontaalinen), yksittäisen toimijan toimintakentän kasvamista (vertikaalinen) sekä sosiaalisen talouden ja solidaarisuustalouden toimijoiden taloudellisen ja poliittisen vaikutusvallan lisääntymistä läpi yhteiskunnan sektorien (transversaalinen). 
Kysymyksenasettelu on herkullinen, sillä tähän skaalautumisen kysymykseen jokainen vaihtoehtoisten talouksien parissa toimiva joutuu vastaamaan. Miten on edes kuviteltavissa, että kovin sirpaleisista ja pienistä talouden vaihtoehdoista voisi rakentua kapitalismia haastava kokonaisuus? Kuinka tuottaa pienistä liikehdinnöistä suurempaa muutosvoimaa? Ja miten laajentua ilman että se tapahtuu hierarkioita moninkertaistamalla, demokratiaa näivettämällä, fossiilienergian kasvun varaan laskemalla? Näiden kysymysten esittäminen on vasta alussa, joten kirjan teema on kutkuttavan akuutti.

Teos jakaantuu johdantoon ja kahteen yhteensä kahdeksantoista lukua sisältävään osaan. Ensimmäinen osa käsittelee yleisemmällä tasolla sosiaalisen ja solidaarisuustalouden historiaa, teoriaa ja strategiaa. Toisessa osassa ääneen pääsevät yhteinen toiminta ja solidaarisuus käytännössä.

Kirjan ensimmäinen puolisko käsittelee esimerkiksi Latinalaisen Amerikan eri valtioiden suhdetta sosiaalisen talouden ja solidaarisuustalouden liikkeisiin, paikallishallinnon tuen merkitystä osuuskuntaliikkeiden onnistumisessa sekä voittoa tavoittelemattomien toimijoiden rakenteellisia eroja suhteessa pörssiyrityksiin. Skaalautumisen kysymykseen pääsee ehkä parhaiten kiinni Reilua kauppaa käsittelevä Darryl Reed. Hän ottaa Reilun kaupan esimerkiksi skaalautumisesta hyvässä ja pahassa. Keskeistä on nähdä sertifiointijärjestelmän sisällä vaikuttavat hyvin erilaiset intressit. Parhaimmillaan Reilu kauppa on mullistanut viljelijöiden elämää turvatumman toimeentulon takeena, tukenut osuuskuntamuotoista talousdemokratiaa sekä luonut globaalin etelän ja pohjoisen välistä solidaarisuutta. Sertifiointijärjestelmänä se on onnistunut skaalautumaan suhteellisen eettisesti tuotettujen ja vaihdettujen hyödykkeiden markkinaosuuksia suurentamalla, tuomalla parempaa tukea pienviljelijöille sekä tuottamalla laajempia hyötyjä paikallisyhteisöille.

Toisaalta merkittävät erot löytyvät Reilun kaupan sertifiointijärjestelmän sisältä, toimijoiden ja arvoketjujen väliltä. Mukaan mahtuu paljolti myös yhteiskuntavastuulla puhtaaksi pestyä suuren mittakaavan bisnestä. Reedin huomio onkin, että kapitalistisen yritystoiminnan poliittiset intressit ja suurten toimijoiden edut ovat pässseet muokkaamaan Reilun kaupan kokonaisuutta liikaa. Tämä vaikuttaa voimakkaasti siihen, millä ehdoin Reilun kaupan skaalautuminen tapahtuu. Johtopäätös on, että sosiaalisen ja solidaarisuustalouden toimijoiden tietoista kollektiivista yhteistyötä tarvitsisi 
lisätä nimenomaan Reilun kaupan sisällä, jotta bisnesorientoitunut puoli ei veisi koko sertifikaatin väljähtymiseen.

Monessa kokoelman artikkelissa nostetaan ansiokkaasti esiin institutionalisoitumisen ja liikeluonteen välistä ristiriitaa. Tämän ristiriidan voi nähdä nousevan jo sosiaalisen talouden ja solidaarisuustalouden käsiteparin jännitteistä. Teemaa nostaa esiin myös esimerkiksi José Luis Coraggio, joka vertailee Latinalaisen Amerikan maiden sosiaalisen ja solidaarisuustalouden poliittisia ympäristöjä toisiinsa. Kiinnostavassa analyysissään maiden eroista Coraggio nostaa esille erityisesti kysymystä siitä, kuinka sosiaalisen ja solidaarisuustalouden ruohonjuuritason liikkeet kykenevät haastamaan ekstraktivistisen talouskasvun varaan rakentuvia instituutioita. Kaikessa ristiriitaisuudessaan Bolivian ja Ecuadorin sosiaalisen ja solidaarisuustalouden muutostyö on onnistunut pureutumaan perustavanlaatuisempiin kysymyksiin (uusien perustuslakien laatimisesta lähtien) kuin naapurimaissa. Toisaalta myös Argentiinassa, Brasiliassa ja Venezuelassa on onnistuttu muuttamaan lainsäädäntöä ja kasvattamaan erilaisen taloudellisen toimijuuden alustaa. Kuitenkin jos tavoitteena on merkittävästi oikeudenmukaisempi ja kestävämpi talous, kaikissa näissä maissa muutos on ollut riittämätön. Coraggion tärkeä kysymys onkin, missä määrin sosiaalinen talous ja solidaarisuustalous kykenevät olemaan tyytymättä institutionaalisiin erävoittoihin ja haastamaan kapitalistisen kasvuun sidottua valtiomuotoa perustavanlaatuisempiin muutoksiin.

Kirjan toisessa osassa käsitellään sosiaalista taloutta ja solidaarisuustaloutta astetta lähempänä käytäntöä lähinnä aluekohtaisten esimerkkien kautta. Jälleen teemojen kirjo on suuri. Esimerkiksi Cristina Grasseni ja kumppanit käsittelevät italialaisia suoramyyntiverkostoja, jotka luovat mafian ja korruption värittämille tuotteiden jakeluketjuille vaihtoehtoja. He käsitteellistävät verkostoja pyörittäviä "solidaarisia hankintaryhmiä" kiinnostavasti sosiaalipedagogisina laboratorioina, joissa opitaan uudenlaista talouden toimijuutta ja vertaisuutta. Paul Nelsonin kirjoituksessa mikrorahoituksesta tehdään erottelu voittoa tavoittelevien ja "pro-sosiaalisten" luotottajien välille. Hänen mukaansa paljon kehuttuja ja parjattuja mikroluottoja voi lähestyä niiden solidaarisuutta arvioivin kriteerein, tapauskohtaisesti, ilman naiivia luottamusta luottojen voimaan tai niiden lähtökohtaista tuomitsemista. Georgina M. Goméz puolestaan kirjaa argentiinalaisen rinnakkaisvaluutan Truequen tarinaa. Trueque oli aikanaan maailman suurin 
rinnakkaisvaluutta. Valuutan skaalautuminen eli käyttöalan kasvu johti sen perustana toimineen luottamuksen rapautumiseen ja monimutkaisiin rakenteellisiin jännitteisiin, jotka kaatoivat lopulta koko hankkeen. Artikkeli kiinnittää huomiota valuuttojen suunnittelun ja hallinnoinnin tärkeyteen. Kaikissa kolmessa esimerkissä korostuu jälleen talouden poliittisuuden prosessiluonne ja pienten käytäntöjen poliittinen merkitys kokonaisuuden suuntautumisessa.

Cecilia Rosselin artikkeli Uruguayn hyvinvointipalveluista tarjoaa mielenkiintoisia opetuksia taloustoimijoiden ja julkisen vallan välisestä suhteesta. Uruguayssa sosiaaliturva on ollut moniin muihin Latinalaisen Amerikan maihin verrattuna suuri. Kuitenkin sosiaalipalvelut ovat käytännössä kerrostuneita ja ihmisryhmiä ulossulkevia. Sosiaalisen talouden ja solidaarisuustalouden toimijat, erityisesti kansalaisjärjestöt, ovat onnistuneesti ottaneet hoitaakseen heikossa asemassa olevien lasten sosiaalipalveluita. Onnistuminen ei kuitenkaan ole yksiselitteistä, sillä järjestöjen vakiintunut asema palvelutuotannossa on vakiinnuttanut myös tiettyjä ongelmallisia asetelmia. Poliittisesta liikehdinnästä on tullut osa systeemiä, minkä seurauksena luovat ratkaisut ja vaatimukset ovat vähentyneet sekä solidaarisuuden ja toimijuuden syventäminen on laantunut.

Samankaltaista dynamiikkaa käsittelee myös Bénédicte Fonteneau artikkelissaan Länsi-Afrikan keskinäisten terveydenhuoltoyhtiöiden kasvusta. Fonteneau korostaa näiden yhteisöjen tasolla toimivien organisaatioiden merkitystä terveydenhuollon ulottamisessa sille enemmistölle, joka ei ole ollut julkisen tai yksityisen sektorin terveydenhuollon turvan piirissä. Hänen mukaansa nämä keskinäiset yhtiöt ovat kyenneet luomaan myös uutta poliittista kulttuuria, jossa kansalaistoimijoiden näkemykset otetaan paremmin huomioon ja ajatus ihmisten yhdenvertaisesta kohtelusta voidaan esittää ratkaistavana haasteena. Fonteneau korostaakin, että näillä talouden toisintekijöillä on palvelutuotannollisen roolin ohella poliittinen tehtävä. Suuri kysymys onkin, millä tavoin talouden haltuunotto voi säilyä jatkuvana poliittisena ja elävänä prosessina yhteiskunnallisesta vakiintumisesta huolimatta.

Lupaavia merkkejä toimintojen skaalautumisesta antaa myös Ananya Mukherjee-Reedin käsittelemä, Intian Keralassa naisten elämää mullistava Kudumbashree -aloite. Kudumbashree on osavaltion hallinnon aloite, joka perustettiin vuonna 1998 köyhyyden vähentämiseksi. Hanke on kasvanut 
ajan myötä moniulotteiseksi. Se yhdistää noin neljä miljoonaa köyhyysrajan alapuolella elävää naista ja koostuu muun muassa yhteisten yritysten perustamisesta, maatalousohjelmasta sekä osavaltion työllisyysohjelmasta. Vaikka kyseessä on hallinnon aloitteesta lähtenyt ohjelma, nimenomaan vertaisuuden synnyttäminen ja toimijuuden vahvistuminen on ollut aloitteen vaikuttavuudessa keskeistä. Esimerkiksi Kudumbashreen osana toimiva maanviljelyohjelma on paitsi vahvistanut sosiaalista koheesiota, myös irrottanut toimeentuloa palkkatyöstä ja lisännyt ruokaomavaraisuutta. Samansuuntaisesta naisten merkitystä korostavasta kehityksestä raportoi myös Bina Agarwal artikkelissaan Intian ja Nepalin yhteisömetsien hallinnasta. Hän korostaa, että vaikka tavoitteena tulee pitää syvällistä solidaarisuuden ja kollektiivisen toimijuuden vahvistumista, on jo muodollisilla askeleilla merkittäviä vaikutuksia. Naisten osallistuminen yhteisömetsiä hallinnoivien ryhmien johtoon on tällainen askel.

Mutta mitkä ovat johtopäätökset? Mitä opimme sosiaalisen ja solidaarisuustalouden skaalautumisesta? Peter Utting nitoo johdantoluvussa kirjan antia yhteen ihailtavan koherentisti. Puhe on nimittäin niin kirjavasta joukosta talouden toimintoja sekä historiallisia ja maantieteellisiä konteksteja, että punainen lanka katoaa kirjaa lukiessa lähes väkisin. Uttingin mukaan keskeistä kirjassa ovat sekä sosiaalisen talouden ja solidaarisuustalouden ristiriidat ja haasteet että mahdollisuudet skaalautumiseen. Ristiriitoja riittää, se artikkeleja lukiessakin käy selväksi. Kirja välttää mainiosti käsiteltävien talouden vaihtoehtojen romantisoinnin. Selvää on esimerkiksi, että monet sosiaalisen talouden ja solidaarisuustalouden toimijat kamppailevat sisäisten jännitteiden (tai niiden kehnojen käsittelymenetelmien) kanssa, kärsivät puutteellisista rahoitusmahdollisuuksista ja muuttavat laajentuessaan muotoaan kapitalististen toimijoiden suuntaan. Lisäksi monet toimijat kärsivät huonosta hallinnosta ja saattavat joutua julkisen vallan marginalisoimiksi. Kokoelma nostaa näitä kipukohtia kiitettävästi esille. Kuitenkin toimintojen arvot ja poliittiset tavoitteet säilyttävä skaalautuminen on mahdollista. Kirja osoittaa mainiosti kuinka tätä ristiriitojen ja jännitteiden kenttää työstetään eri puolilla maailmaa.

Kaiken kaikkiaan teos on mielenkiintoinen kokoelma. Se natisee liitoksistaan teemojen ja kontekstien kirjavuuden vuoksi, mutta pysyy kasassa. Erityisen painavaa sanottavaa sillä on liittyen taloudellisten toimintojen institutionaaliseen kontekstiin, sisäisiin ristiriitoihin sekä laajentumisen 
haasteisiin. Tapaustutkimusten aiheista kiinnostuneille se antanee kiinnostavan kehystyksen sosiaalisen talouden ja solidaarisuustalouden käsitteellä. Harmi kyllä, skaalautumisen haasteet otetaan joissakin artikkeleissa turhan ohimenevästi käsittelyyn ja talouden muotojen suhde yhteiskunnalliseen muutosvoimaan jää monelta kohdin turhan etäiseksi. Tällä kirjalla ei selvästikään vallata peltoja tai tehtaita, mutta talouden liikkeiden institutionalisoitumisesta sillä on paljonkin sanottavaa. Myös ekologisen kriisin konteksti jää harmillisesti pimentoon kirjassa. Herää kysymys, voidaanko talouksien skaalautumista tai ylipäätänsä poliittisen talouden tulevaisuutta käsitellä mielekkäästi ilman voimakasta ja läpileikkaavaa ekologista arviointia. Ainakin tämän kirjan olohuoneessa tallustelee vielä melkoinen elefantti.

\section{Lähteet}

Jakonen, Mikko ja Silvasti, Tiina (toim.). 2015. Talouden uudet muodot. Helsinki: Into. 